\title{
Feeding selectivity of the harpacticoid copepod Canuella perplexa in benthic muddy environments demonstrated by HPLC analyses of chlorin and carotenoid pigments
}

\author{
Evelyne Buffan-Dubau, Rutger de Wit, Jacques Castel* \\ Laboratoire d'Océanographie Biologique, Université Bordeaux I, CNRS-URA 197, 2 rue du Professeur Jolyet, \\ F-33120 Arcachon, France
}

\begin{abstract}
The natural diet and the feeding selectivity of the harpacticoid copepod Canuella perplexa T \& A. Scott, 1893 were studied in submerged muddy sediments of artificial lagoons in Arcachon Bay (SW France). This study focused on the role of phototrophic microorganisms as food sources. Therefore, chlorin and carotenoid pigments in copepods were compared with those present in the top $3 \mathrm{~cm}$ of the sediment. High performance liquid chromatography with on-line measurement of absorption spectra was used for separation, identification, and quantification of pigments. Diatoms, purple phototrophic bacteria, cyanobacteria, and green microalgae contributed to the benthic phototrophic community. C. perplexa ingested diatoms and infrequently cyanobacteria and/or green microalgae in preference to purple phototrophic bacteria. Ingested chlorophyll a was converted into phaeophytin and phaeophorbide-like compounds. Moreover the copepod synthesized astaxanthin and a related isomer most likely from ingested $\beta$-carotene.
\end{abstract}

KEY WORDS: HPLC Pigment - Harpacticoid copepod Canuella perplexa Gut content - Natural diet Muddy sediment

\section{INTRODUCTION}

Harpacticoid copepods feed on microalgae (Rieper 1985, Decho 1988), protozoans (Rieper \& Flotow 1981), bacteria (Rieper 1978), and organic detritic particles (Rudnick 1989, Rieper-Kirchner et al. 1991). In addition, a number of field studies have described positive spatial and temporal correlations between benthic copepods and microphytobenthos abundances (e.g. Decho \& Fleeger 1988a, Trueblood et al. 1994). Laboratory experiments have shown that feeding selectivity is common among harpacticoids (Rieper 1982, Decho \& Castenholz 1986). It has been reported that selectivity is species-specific (Vanden Berghe \& Bergmans 1981), and additionally, within some species, changes of selectivity can occur throughout developmental stages

-Addressee for correspondence.

E-mail: j.castel@biocean.u-bordeaux.fr
(Decho \& Fleeger 1988b). Benthic copepods are themselves an important food source, particularly for epibenthic organisms such as shrimps and juvenile fish (Alheit \& Scheibel 1982, Gee 1987, Castel 1992)

Radioisotopic tracers have been used in most field feeding studies since, currently, this is the only method available to measure grazing on both bacteria and microalgae in natural sediments (see review in Montagna 1995). Thus, it has been found that harpacticoid copepods adjust their grazing rates on the microbial community in response to variations in environmental conditions such as temperature, season, and food quality (Montagna 1984, Blanchard 1991, Montagna \& Yoon 1991, Montagna et al. 1995). From these field studies it has been estimated that in shallow water ecosystems the major meiofaunal taxa (i.e. nematodes and benthic conepods) graze at a rate of $1 \%$ of the microbial standing stock of both heterotrophs and autotrophs per hour, worldwide (Montagna 1995). Field studies of interactions 
among harpacticoid species and feeding strategies are not common. Carman \& Thistle (1985), using radioisotopic tracers, have suggested that co-occurring species may adopt different feeding strategies in natural sediments: i.e. Thompsonula hyaenae preferred microalgae, Halicyclops coulli preferred bacteria, and Zausodes arenicolus did not exhibit preference. However, due to methodological problems (see e.g. Montagna \& Bauer 1988, Carman 1990), the preference exerted by copepods on bacteria has probably been overestimated and the feeding behaviour of harpacticoid copepods in their matural environment remains poorly understood.

The aim of the present study is to describe the natural feeding selectivity of the benthic copepod Canuella perplexa T. \& A. Scott, 1893. C. perplexa is a large harpacticoid copepod (1 to $1.3 \mathrm{~mm}$ adult size), common in coastal environments in the northern hemisphere (Heip 1973, Castel 1992, Ceccherelli et al. 1994). We focused on phototrophic micioorganismis as food sources using chlorin and carotenoid pigments as biomarkers. Therefore, for the first time, we applied the HPLC pigment analysis technique to benthic copepods and evaiudied the merits and limitations of this technique for field studies. In comparison to fluorimetric analysis, the HPLC technique is more accurate because of pigment separation which avoids interferences amongst pigments. This technique has previously been shown to be useful for the study of dietary selectivity of planktonic copepods in both laboratory (Head \& Harris 1994) and field investigations (Kleppel et al. 1988, Swadling \& Marcus 1994) because it allows tracking of biomarker pigments from the water column to the copepod gut and finally to the fecal pellets. We compared the pigment content of $C$. perplexa sampled in the field with the pigment composition of the sediment. In a previous study, Buffan-Dubau \& Castel (in press) demonstrated that this copepod species migrates vertically within the muddy sediments of the fish ponds of Arcachon Bay (France) between the surface and a depth of $3 \mathrm{~cm}$. Thus, in addition to microalgae found in the surface layer of the sediment, this copepod may feed on anoxygenic phototrophic organisms, which have been found to be abundant to a depth of $5 \mathrm{~cm}$ (Guyoneaud et al. in press). The latter hypolhesis is supported by the fact that several harpacticoid copepods use purple phototrophic bacteria as a food source (Rieper 1984, Decho \& Castenholz 1986, SouzaSantos et al. in press).

\section{MATERIALS AND METHODS}

Study site and sampling stations. Sampling was undertaken in the fish ponds of Arcachon Bay $\left(44^{\circ} 40^{\prime} \mathrm{N}, 1^{\circ} 10^{\prime} \mathrm{W}\right)$, Atlantic coast of SW France, which are semi-enclosed, shallow lagoonal systems (see description by Castel et al. in press). In these man-made enclosures created in the marshes, a number of euryhaline fish are farmed: grey mullet (Chelon labrosus Risso, Liza ramada Risso), sea bass (Dicentrarchus labrax Linné), eels (Anguilla anguilla Linné). The ponds are separated from the bay by embankments through which the renewal of water is regulated by sluices. The sediments, which are partly covered by canopies of the seagrass Ruppia cirrhosa, are rich in organic detritus (POC, particulate organic carbon, content 3.3 to $8.7 \%$ ) and silt (36 to $58.4 \%$ ) (Escaravage \& Castel 1989). Copepods were collected on March 28, 1994, at Stn $C_{1}$ (Ca $0.4 \mathrm{~m}$ water depth, $S=10 \%$, sediment $T=16^{\circ} \mathrm{C}$ ) and on October 15 , 1994, at Stn G (ca $0.6 \mathrm{~m}$ water depth, $S=29 \%$, sediment $T=19^{\circ} \mathrm{C}$ )

Laboratory preliminary experiment. A laboratory cxperiment was performed to study the feasibility of the approach for subsequent field applications. Living individuals of Canuella perplexa sampled at Stn $C_{1}$ were carefully separated from fresh sediment under a dissection microscope using a Pasteur pipette. They were starved for $12 \mathrm{~h}$ in filtered seawater $(0.22 \mu \mathrm{m})$ and subsequently fed for $24 \mathrm{~h}$ at constant temperature $\left(20^{\circ} \mathrm{C}\right)$ with a unialgal culture of a benthic diatom Nitzschia sp. in excess (ca $7 \times 10^{5}$ cells $\mathrm{mi}^{-1}$ ). This strain was previously isolated from the sediment of the fish ponds. After verification of the gut fullness by microscopic observations, the copepods were killed by freezing $\left(-20^{\circ} \mathrm{C}\right)$. Two copepod samples comprising 150 and 300 individuals were prepared and immediately analysed by HPLC (see below). Pigments from the Nitzschia sp. culture were also analysed. From this experiment we determined the minimum sample size (i.e. the number of copepods per sample) needed for identification and quantification of the major pigments in the gut using our HPLC system. Furthermore, we studied possible conversions of the ingested pigments into other coloured compounds

Field comparison of pigment composition of copepods and total sediment samples. Sediment samples were hand collected using plastic core tubes $3 \mathrm{~cm}$ internal diameter and $5 \mathrm{~cm}$ length). Cores were immediately frozen in liquid nitrogen and then returned to the laboratory in ice-filled coolboxes ( $1 \mathrm{~h}$ transportation time). In the laboratory, they were stored in the dark at $-20^{\circ} \mathrm{C}$ for a maximal period of around $4 \mathrm{mo}$. It has been previously reported that no discernable changes in pigment composition occur during equivalent periods (Wright et al. 1991).

Copepod sorting was conducted under minimum light exposure to prevent pigment degradation. Approximately 80 frozen sediment cores were used 
for harvesting copepods. The upper 0 to $3 \mathrm{~cm}$ depth horizon of each core was gently thawed and washed under a flow of tap water through a $200 \mu \mathrm{m}$ sieve to selectively retain adults and older copepodite stages of Canuella perplexa. Groups of ca 50 individuals were separated from the sediment under a dissection microscope (sorting duration $\sim 20 \mathrm{~min}$ ). Copepods were washed twice in filtered $(0.22 \mu \mathrm{m})$ seawater to remove coloured epicuticular particles (this was controlled under dissection microscope), immediately frozen and preserved at $-20^{\circ} \mathrm{C}$ in the dark until the end of the sorting procedure. Excess water was removed from the copepod samples either using a Pasteur pipette under a dissection microscope (March samples) or by $3 \mathrm{~h}$ freeze-drying (October samples). The pigments were immediately extracted from the copepods. The minimum sample size was estimated from the previous laboratory experiment. Indeed, results indicated that 300 copepods fed in the laboratory culture represented a minimum sample size to analyse pigments in copepods in detail. We assumed that in situ copepods may ingest lower pigment amounts; therefore, we prepared field samples from at least 400 individuals. During the first experiment in March the copepods were systematically sorted from the sediment without distinction between 'full' and 'empty' individuals, and 2 samples were prepared comprising 400 and 560 individuals. In order to check if the feeding behaviour was essentially similar at another period of the year, we repeated the experiment in October. Since the latter samples were analysed with a less sensitive Perkin Elmer detector system (see below), the signal needed to be enhanced. Therefore, $C$. perplexa was sampled from Stn $G$, where this species was particularly abundant, selecting individuals which appeared 'full.' under the dissection microscope (ca $50 \%$ of the individuals). Thus, 2 samples were prepared which comprised 1011 and 1447 'full' individuals.

Pigment extraction procedure (Fig. 1). Pigments were extracted from the copepods by sonication (Bioblock 72446 sonicator, 50 W, 3 mm diameter probe) of each sample for $10 \mathrm{~s}$ in $4 \mathrm{ml} 100 \%$ cold acetone (HPLC Merck quality) followed by incubation (12 h) in the dark at $-20^{\circ} \mathrm{C}$ under a nitrogen atmosphere. Copepod debris was separated from the pigment extracts by centrifugation ( $5 \mathrm{~min}, 2500 \mathrm{rpm}, 720 \times \mathrm{g}$ ). The extracts were concentrated by solvent evaporation under a flow of nitrogen to enhance the signal. Extracts were stored in the dark at $-20^{\circ} \mathrm{C}$ under nitrogen to prevent oxidation and analysed within a few hours as described below.

Fū̃ àualysis of sediment plgment content, 3 frozen replicate cores per sampling were sliced at $1 \mathrm{~cm}$ depth intervals from 0 to $3 \mathrm{~cm}$ depth, and the slices were

\section{COPEPOD SAMPLES FROZENSEDIMEVT}

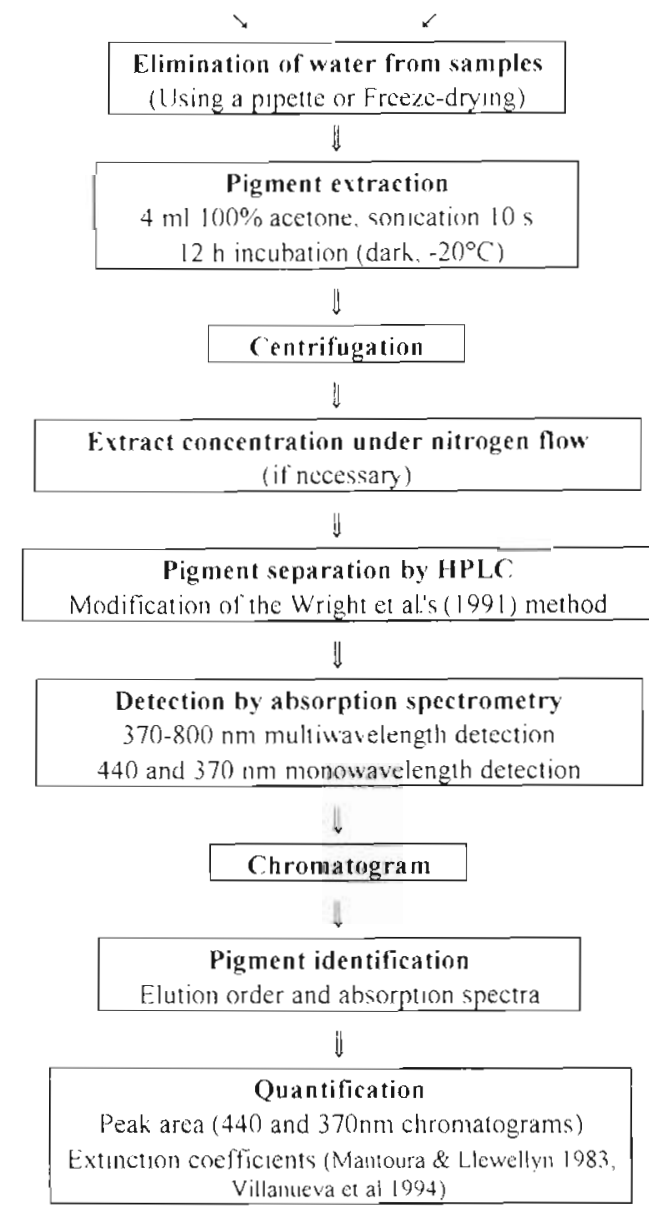

Fig. 1. Flow chart of the different stages constituting the HPLC pigment analysis method used in this study

freeze-dried prior to pigment extraction. The pigments were extracted by sonication of each sample for $10 \mathrm{~s}$ in $100 \%$ cold acetone $(4 \mathrm{ml}$ acetone to 250 to $800 \mathrm{mg}$ dry weight sediment) and incubation for $12 \mathrm{~h}$ in the dark at $-20^{\circ} \mathrm{C}$. The extracts were separated from the sediment by centrifugation.

Reference cultures were used to obtain pigment standards as recommended by the SCOR Working Group 78 (Wright et al. 1991). Microalgal cultures (Phaeodactylum tricornutum and Dunaliella tertiolecta) were maintained in the medium of Guillard \& Ryther (1962) at $20^{\circ} \mathrm{C}$ under a $12 \mathrm{~h}$ dark: $12 \mathrm{~h}$ light photoperiod. The cyanobacterium Phormidium valderianum was cultivated according to Grimalt et al. (1992) and the purple phototrophic bacterium Thiocapsa roseopersicina was cultivated as described in Guyoneaud et al. (in press). Aliquots of reference rultures $(15 \mathrm{ml})$ were centrifuged to separate cells from the culture medium. Pigments were extracted from the culture pellets by sonication (15 s) in $5 \mathrm{ml} 100 \%$ cold 
acetone and $12 \mathrm{~h}$ incubation in the dark at $-20^{\circ} \mathrm{C}$ under nitrogen. Pigment extracts were separated from cell fragments by centrifugation. Pigment extracts from sediment samples and reference cultures were stored under nitrogen atmosphere in the dark at $-20^{\circ} \mathrm{C}$ and analysed within $3 \mathrm{~d}$.

HPLC with on-line measurement of absorption spectra of separated pigments. The HPLC system comprised a Perkin Elmer LC250 binary solvent delivery system coupled to a photometric detector. All copepod samples and extracts from 1 sediment core from Str $C_{1}$ (March) were studied using a Spectra Physics Focus 2000 SF 202-0100 fast-scanning (70 scans $\mathrm{s}^{-1}$ ) spectrophotometer programmed to obtain the on-line absorption spectra from 370 to $800 \mathrm{~nm}$. Blank injections (pure acetone) showed that background noise on this system was less than $5 \times 10^{-5}$ AU (absorbance units) over the entire wavelength range studied. In addition, replicate cores from Stn $C_{1}$ were siudied. These samples and all samples from Stn G (October) were studied using a Perkin Elmer LC 290 UV/VIS monowavelength detector, which had a background noise of approximately $10^{-3.3}$ AU. Extiacts from these samples were analysed twice with the monowavelength detector set at $440 \mathrm{~nm}$ and at $370 \mathrm{~nm}$, for the detection of carotenoids + algal chloropigments + their degradation products and bacteriochlorophyll a + its degradation products respectively.

The separation of pigments was performed by reverse-phase liquid chromatography using a $250 \mathrm{~mm} \times$ $5 \mathrm{~mm}$ i.d. column packed with octadecylsilane (LiChrospher RP-18, $5 \mu \mathrm{m}$, Merck). We modified the method described by Wright et al. (1991) for use with a binary solvent delivery system. The mobile phase (eluents) was programmed according to the gradient shown in Table 1; solvent A consisted of methanol, $0.5 \mathrm{M}$ ammon:um acetate (Fluka) in bidistilled water $(\mathrm{pH} 7.2)+$ acetonitrile $(80 / 10 / 10, \mathrm{v} / \mathrm{v} / \mathrm{v})$ and solvent $B$ was ethyl acetate. All organic solvents were HPLC grade (methanol: Prolabo; others: BDH Hypersolv). Complete elution of all pigments was achieved within

Table 1. HPLC solvent system program used in this study

\begin{tabular}{|cccl|}
\hline $\begin{array}{c}\text { Time } \\
(\mathrm{min})\end{array}$ & $\begin{array}{c}\text { Flow rate } \\
\left.(\mathrm{ml} \mathrm{min})^{-1}\right)\end{array}$ & $\begin{array}{c}\% \text { solvent } \\
\text { A }\end{array}$ & Conditions \\
\hline 0 & 1.0 & 100 & Injection \\
10 & 1.0 & 60 & Concave gradient \\
5 & 1.0 & 50 & Convex gradient \\
5 & 1.0 & 50 & Isocratic phase \\
15 & 1.0 & 10 & Concave gradient \\
10 & 1.0 & 100 & Concave gradient \\
10 & 1.0 & 100 & Equilibration \\
& & & \\
\hline
\end{tabular}

45 min. Extracts $(100 \mu l)$ were injected using a calibrated loop coupled to a Rheodyne injection valve (8125)

The pigments were identified by comparing the retention time and the absorption spectra with those of standard compounds, which were either authentic standards (chl $a$ and chl $b$, Sigma-Aldrich Fallavier, France) or obtained from reference cultures (strain sources are listed in Table 2). Furthermore, phaeophytin a and bacteriophaeophytin a were prepared by acidifying solutions of chl a and extracts of Thiocapsa roseopersicina respectively. Phaeophorbide-like compounds were identified by comparison of absorption spectra and elution order with literature data (Wright et al. 1991). These compounds include the corresponding pyrophaeopigments, which are $\mathrm{C}-13^{2}$ carbomethoxy defunctionalized (Villanueva et al. 1994). The loss of this functional group virtually does not affect the absorption spcctrum. Pigments were quantified from the peak area using the extinction coefficients listed by Mantoura \& Llewellyn (1983) and by Villanueva et al. (1994). With our system, chl a and the bacterial carotenoid spirilloxanthin coeluted; however, quantification was possible by comparing the contribution to absorbance at $440 \mathrm{~nm}$ (both compounds), $490 \mathrm{~nm}$ (only spirilloxanthin), and $665 \mathrm{~nm}$ (only chl a).

\section{RESULTS}

\section{Laboratory preliminary experiment}

The results of the laboratory experiment with Canuella perplexa are shown in Fig. 2. Five of the 8 pigments identified in the extract of these copepods corresponded to the major pigments from the Nitzschia sp. culture used as food. These comprised chl $c(2)$, fucoxanthin (4), diadinoxanthin (11), chl a (22), and $\beta$-carotene (28). Furthermore, the sample contained minor amounts of phaeophorbide $a$ (3) and 2 compounds $(12,13)$, which were also absent in the Nitzschia culture. The absorption maxima of $477 \mathrm{~nm}$ (12) and $474 \mathrm{~nm}$ (13), as well as the shape of the absorption spectra of these compounds 11 broad maximum, see Fig. 2b), match those described previously for astaxanthin (Hairston 1979). The absorption maximum of astaxanthin is between 470 and $478 \mathrm{~nm}$. depending on the solvent (Herring 1972, Paanakker \& Hallegraeff 1978, Byron 1982). Since the C. perplexa individuals were slightly pink in coloration, we suggest that these astaxanthin isomers contribute to body pigmentation and are synthesised from $\beta$-carotene, as previously reported for many planktonic copepods (Fisher et al. 1964, Paanakker \& Hallegraeff 1978, Hairston 1979, Kleppel et al. 1988). 
Table 2. Elution order and absorption charateristics of pigments identified from acetone extracts of sediment and copepod individuals. Source organisms and literature (1, Wright et al. 1991; 2, Villanueva et al. 1994; 3. Hairston 1979; Paanakker \& Hallegraeff 1978) used for the pigment identification are also shown. For absorption maxima the first value refers to the highest absorption maximum; values in paren-theses represent a more or less marked shoulder formed by the curve of the absorption spectra

\begin{tabular}{|c|c|c|c|c|}
\hline Peak no. & Identified pigment & Absorption maxima ( $\mathrm{nm}$ ) & Source for identification & Reference \\
\hline 1 & Chlorophyllide a & $430 / 666$ & Phatodactylum tricornutum ${ }^{\circ}$ & 1 \\
\hline 2 & Chlorophyll $c$ & $442 / 633$ & Phaeodactylum tricornutum & 1 \\
\hline 3 & Phaeophorbide a-like, & $410 / 666$ & & 1 \\
\hline 4 & Fucoxanthin & 450 & Phaeodactylum tricornutum & 2 \\
\hline 5 & Cis-fucoxanthin-like $_{1}$ & 444 & Phaeodactylum tricornutum & 1 \\
\hline 6 & Phaeophorbide a-like 2 & $410 / 666$ & & 1 \\
\hline 7 & Cis-fucoxanthin-like $e_{2}$ & 446 & Phaeodactylum tricornutum & 1 \\
\hline 8 & Unidentified carotenoid & 441 & & \\
\hline 9 & Phaeophorbide a-like 3 & $410 / 666$ & & 1 \\
\hline 10 & Phaeophorbide a-like $e_{4}$ & $410 / 666$ & & \\
\hline 11 & Diadinoxanthin & $447 / 475$ & Phaeodactylum tricornutum & 1 \\
\hline 12 & Astaxanthin ${ }^{\natural}$ & 477 & Canuella perplexa (copepod) & 4 \\
\hline 13 & Astaxanthin (isomer of 12$)^{\mathrm{c}}$ & 474 & Canuella perplexa (copepod) & 3 \\
\hline 14 & Zeaxanthin & $451 / 425 /(480)$ & Phormidium valderianum & 2 \\
\hline 15 & Zeaxanthin-like & $451 /(425) / 480$ & Phormidium valderianum & 2 \\
\hline 16 & Phaeophorbide a-like ${ }_{5}$ & $410 / 666$ & & 1 \\
\hline 17 & Lutein & $448 /(420) 474$ & Dunaliella tertiolecta ${ }^{\mathrm{e}}$ & 1 \\
\hline 18 & Lutein-like & $448 /(420) / 474$ & Dunaliella tertiolecta & 1 \\
\hline 19 & Unidentified carotenoid & 490 & & \\
\hline 20 & Bacteriochlorophyll a & $771 / 600$ & Thiocapsa roseopersicina ${ }^{\mathrm{d}}$ & 2 \\
\hline 21 & Chlorophyll a allomer & $426 / 664$ & & 1 \\
\hline 22 & Chlorophyll a & $431 / 666$ & Standard & 1 \\
\hline 22 & Spirilloxanthin ${ }^{b}$ & $491 / 483$ & Thiocapsa roseopersicina & 2 \\
\hline 23 & Chlorophyll a epimer & $431 / 666$ & & 1 \\
\hline 24 & Bacteriophaeophytin a-like $e_{1}$ & $746 / 526$ & Thiocapsa roseopersicina' & 2 \\
\hline 25 & Bacteriophaeophytin a-like 2 & $739 / 530$ & Thiocapsa roseopersicina' & 2 \\
\hline 26 & Phaeophytin a-like $_{1}$ & $410 / 665$ & Chl a standard 9 & 1 \\
\hline 27 & Phaeophytin a-like $e_{2}$ & $410 / 667$ & Chl a standard 9 & 1 \\
\hline 28 & $\beta$-Carotene & $453 / 418 / 478$ & Phaeodactylum tricornutum & 1 \\
\hline
\end{tabular}

\section{Sediment pigment content}

The pigments identified from sediment extracts are listed in Table 2 and examples of chromatograms are shown in Fig. 3. Among biomarker pigments, chl $C$ (2), fucoxanthin (4), diadinoxanthin (11), and $\beta$ carotene (28) were detected in the sediment indicating that diatoms contributed to the microphytobenthos. Peridinin and fucoxanthin derivatives such as 19'-hexanoyloxyfucoxanthin and 19'-butanoyloxyfucoxanthin were not detected. This indicates that other chromophyte algae containing fucoxanthin and dinophyceans were absent or poorly represented in the community (see Table 3). Absorption spectra of carotenoid peaks $14,15,17$ and 18 corresponded to those of lutein and zeaxanthin. Thus, green microalgae and probably cyanobacteria also contributed to the microphytobenthic community of the fish ponds.
Finally, bacteriochlorophyll a (20), bacteriophaeophytin $a(24,25)$, and the carotenoid spirilloxanthin $(22$, coeluting with chl a) were detected, demonstrating the presence of purple phototrophic bacteria in the sediment (Fig. 3c). Chl a and bacteriophaeophytin a were the major chloropigments for both samplings (Table 4). The chlorophyll/phaeopigments ratios, averaging 4 and 0.4 for algal pigments and bacteriopigments respectively, indicated that the microalgae and cyanobacteria were in a viable state whilst most of purple phototrophic bacteria were in a senescent or detritic state.

\section{Copepod pigment content}

The pigments identified from extracts of field copepods are listed in Table 4 and examples of chro- 

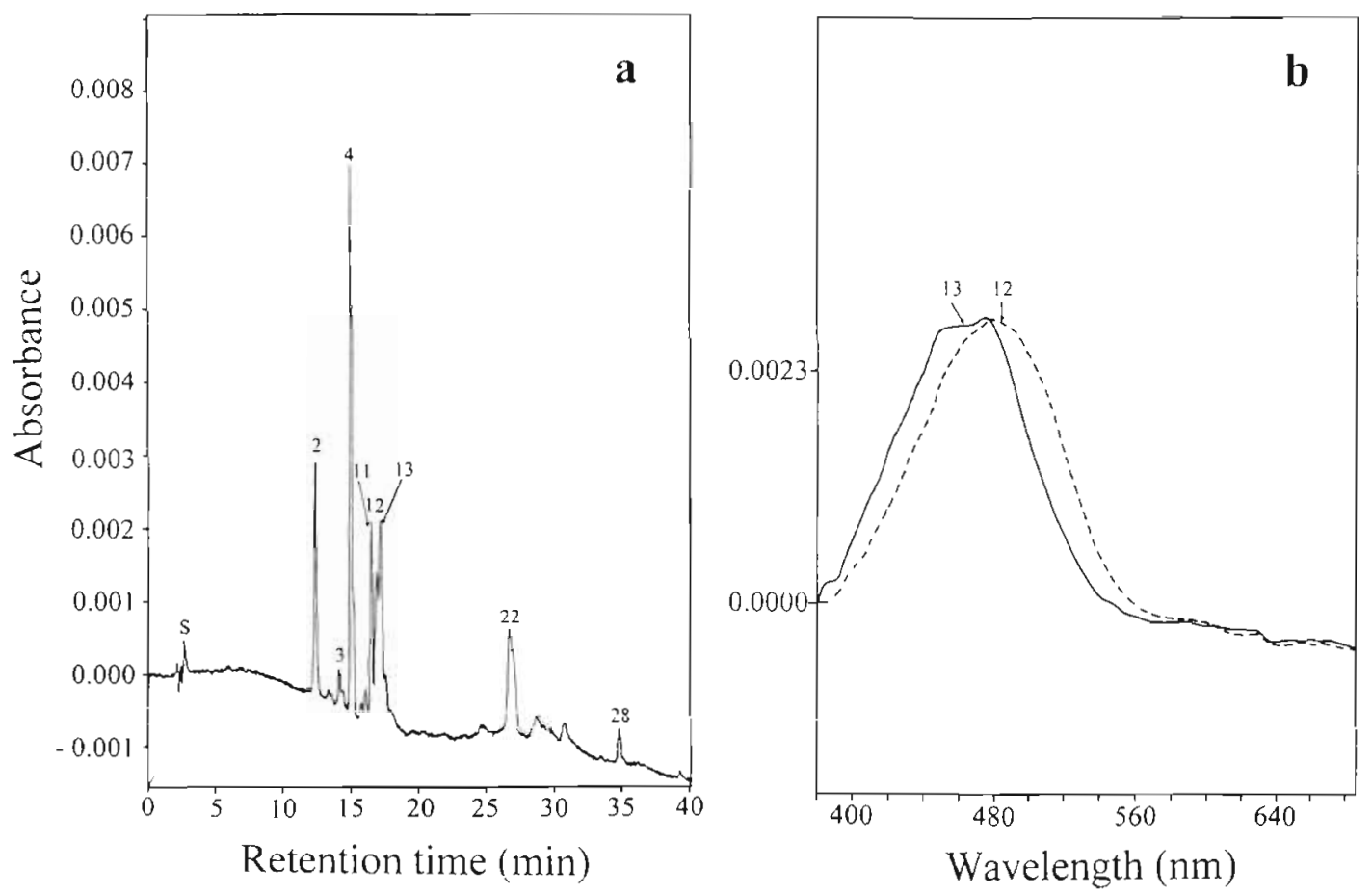

Fig. 2. Canuella perplexa. (a) Absorbance chromatogram $(440 \mathrm{~nm}$ ) of the extract comprising 300 individuals which were fed on a diatom culture (Nitzschia sp.) in the laboratory, (for peak identification see Table 2). S: solvent peak. (b) A.bsorption spectra of carotenoids 12 and 13 that originated from the copepod body pigmentation (astaxanthin and derivative isomer)

Table 3. Summary of the biomarker pigments which were searched for in copepods and sediment samples and the microorganism types they could represent in the fish pond sediments. References: 1, Bianchi et al. (1.988); 2, Stauber \& Jeffrey (1988);

3. Wright et al. (1991); 4, Villanueva et al. (1994)

\begin{tabular}{|c|c|c|}
\hline Biomarker & Algal/bacterial type & Reference \\
\hline \multicolumn{3}{|l|}{ Chlorophylls } \\
\hline Chl a & Phytobenthos and phytoplankton, vascular plants & $1,2,3,4$ \\
\hline Ch]. $b$ & Green algae, vascular plants & 1,3 \\
\hline Chl $c$ & Diatoms and other chromophyte algae & 2,3 \\
\hline Bacteriochlorophyll a & Phototrophic purple bacteria & 4 \\
\hline \multicolumn{3}{|l|}{ Carotenoids } \\
\hline Fucoxanthin & Diatoms and other chromophyte algae, a few dinophyceans & 2,3 \\
\hline $\left.\begin{array}{l}\text { 19'-Hexanoyloxyfucoxanthin } \\
19^{\prime} \text {-Butanoyloxyfucoxanthin }\end{array}\right\}$ & Some chromophyte algae, $l$ diatom, a few dinophyceans & 2,3 \\
\hline Diadinoxanthin & Diatoms and other chromophyte algae, pyrrophyte algae & 2,3 \\
\hline Zeaxanthin & Cyanobacteria, green microalgae & 3,4 \\
\hline Lutein & Green microalgae, vascular plants & 1,3 \\
\hline Peridinin & Dinophyceans and other pyrrophyte algae & 3 \\
\hline$\beta$-Carotene & Algae, vascular plants & $1,2,3,4$ \\
\hline Spirilloxanthin & Some phototrophic purple bacteria & 4 \\
\hline \multicolumn{3}{|l|}{ Degradation products } \\
\hline Phaeophytin $a$ & Chl a degradation & $1,3,4$ \\
\hline Phaeophorbide a & Chl a degradation & $1,3,4$ \\
\hline Bactenophaeophytin a & Bacteriochlorophyll a degradation & 4 \\
\hline
\end{tabular}



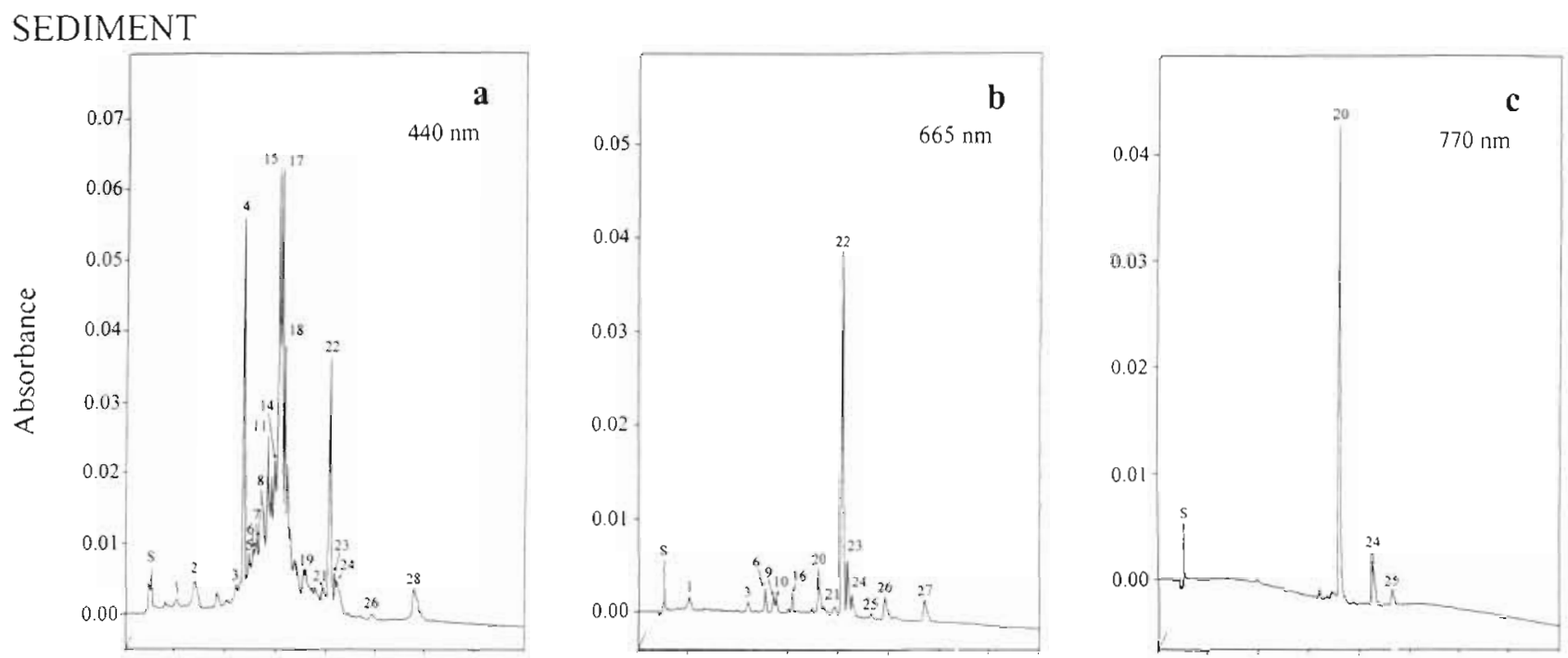

\section{COPEPODS}
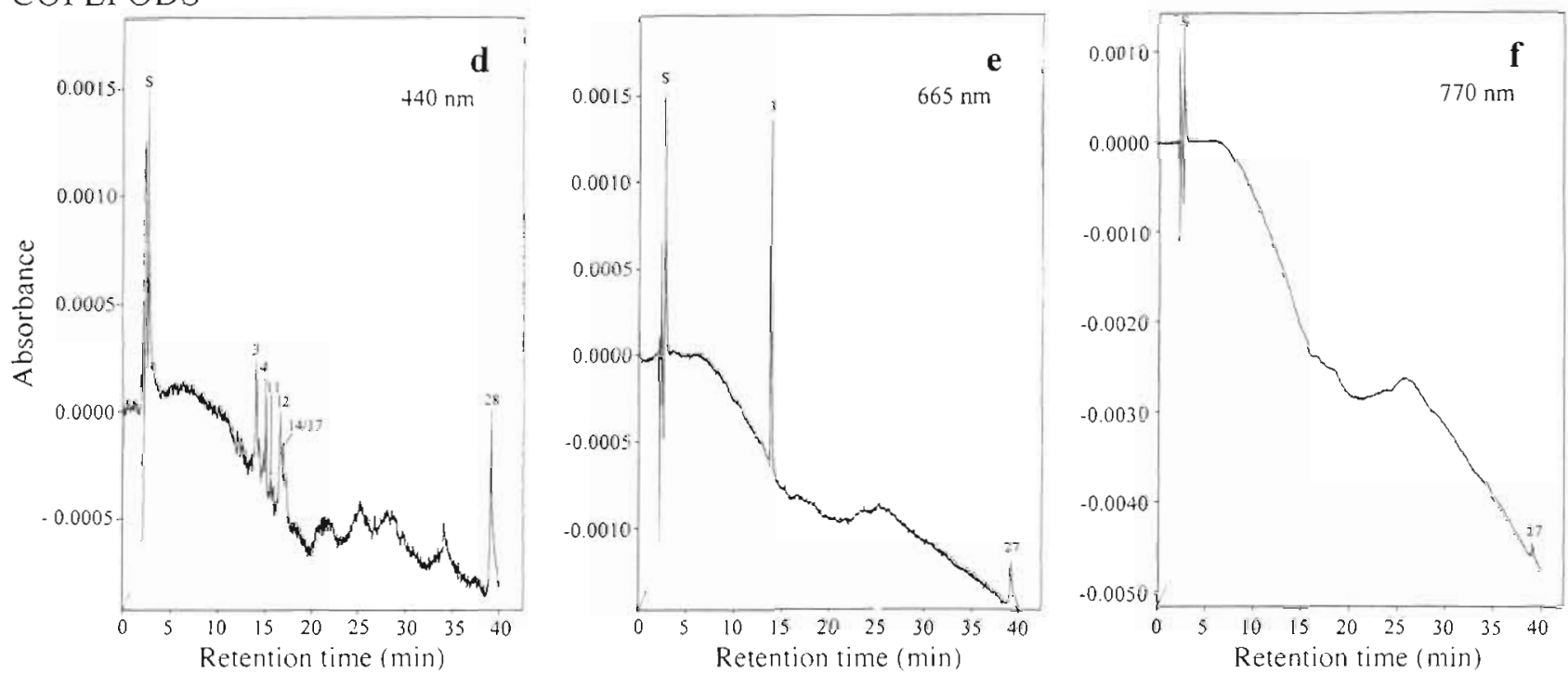

Fig. 3. Canuella perplexa. Absorbance chromatograms of $(a-c)$ extracts from muddy sediments representing the habitat of the copepods, 1 to $2 \mathrm{~cm}$ depth horizon, and (d-f) extracts of the copepods collected in the field (sample comprising $400 \mathrm{individuals}$ ): March 1994, Stn $C_{1}$. For peak identification see Table 2. S: solvent peak

matograms from the March sampling are shown in Fig 3. The main difficulty encountered during the identification of pigments in acetone extracts of copepods collected in the field was due to the low concentrations with low absorbance values causing some distortions of the absorption spectra. However, using elution order and absorption characteristics, the major peaks in the chromatograms were identified (Fig. 3). The carotenoids fucoxanthin and diadinoxanthin were detected in both the March and the October samples. Iñ cunilitasi, a carotenold peak with a retention time and absorption maxima $(425,445$, and $472 \mathrm{~nm}$ ), indicative of coeluting zeaxanthin + lutein, was found only in the March samples (Fig. 3d, 14, 17). In addition, March chromatograms showed a carotenoid peak with a retention time and an absorption spectrum (absorption maximum at $477 \mathrm{~nm}$ ) which matched those of astaxanthin (cf. Fig. 2b). Decoloration of several copepods was observed during copepod sorting and particularly during freeze-drying. Considering that only October samples were freeze-dried, we do not recommend this treatment. Thus, the calculated concentrations of astaxanthin should he considered as minimum values (Table 4). Astaxanthin was quantified assuming an extinction coefficient of 2099 (Herring 1972). Finally, algal chloropigments such as chl $a$, 
Table 4. Canuella perplexa. Quantification of pigments contamed in sediment samples ( $\mu \mathrm{g}^{-1}$ of dry sediment, mean values of the 0 to $3 \mathrm{~cm}$ layer $\pm \mathrm{SD}$ ) and in copepod samples (ng ind, ${ }^{-1}$ ) collected in March 1994 (Stn $\mathrm{C}_{1}$ ) and in October 1994 (Stn G) using peak area measurements from chromatograms at $440 \mathrm{~nm}$ (algal pigments) and at $370 \mathrm{~nm}$ (bacteriopigments). The copepods were adults or large copepodites. From Stn G, only individuals with full stomachs were used. S1: Sample 1. S2: Sample 2 n: number of individuals per sample. -: pigment not detected. nq: not quantified

\begin{tabular}{|c|c|c|c|c|c|c|}
\hline \multirow[t]{3}{*}{ Pigment } & \multicolumn{2}{|c|}{ Sediment $\left(\mu \mathrm{g} \mathrm{g}^{-1}\right)$} & \multicolumn{4}{|c|}{ Copepod content (ng ind. ') } \\
\hline & \multirow{2}{*}{ March } & \multirow[t]{2}{*}{ October } & \multicolumn{2}{|c|}{ March } & \multicolumn{2}{|c|}{ October } \\
\hline & & & $\mathrm{S} 1(\mathrm{n}=400)$ & $S 2(n=560)$ & $\mathrm{S} 1(\mathrm{n}=1011)$ & $\$ 2(n=1447)$ \\
\hline Chlorophyll a & $21.80 \pm 5.09$ & $17.78 \pm 4.49^{\mathrm{dt}}$ & - & 0.0032 & 0.4487 & 0.1369 \\
\hline Phaeophytin a-like & $4.85 \pm 0.80$ & $2.25 \pm 0.73$ & 0.0056 & - & 0.6028 & 0.21 .75 \\
\hline Phaeophorbide a-like & $1.69 \pm 0.92$ & $1.45 \pm 0.62$ & 0.0143 & 0.0104 & 0.2833 & 0.0154 \\
\hline Chlorophyll c & - & $0.02 \pm 0.02$ & - & - & - & - \\
\hline Bacteriochl a & $5.87 \pm 3.39$ & $1.83 \pm 0.55$ & - & - & - & - \\
\hline Bacteriophaeophytin a & $21.17 \pm 8.03$ & $3.43 \pm 2.05$ & - & - & - & - \\
\hline Fucoxanthin & $1.52 \pm 0.86$ & $1.25 \pm 0.52$ & 0.0065 & 0.0129 & 0.0164 & 0.0118 \\
\hline Diadinoxanthin & $2.41 \pm 1.36$ & $1.09 \pm 0.12$ & 0.0017 & 0.0029 & - & 0.0086 \\
\hline Astaxanthin & - & - & 0.0045 & 0.0122 & - & - \\
\hline Zeaxanthin+lutein-like & $2.22 \pm 0.83$ & $1.89 \pm 0.31$ & 0.0045 & 0.0035 & - & - \\
\hline Spirilloxanthin & $2.90 \pm 0.66$ & nq & - & - & no data & no data \\
\hline B-Carotene & $2.11 \pm 0.38$ & $1.12 \pm 0.42$ & 0.0078 & - & 0.1490 & 0.0286 \\
\hline Total pigments & $66.54 \pm 22.32$ & $32.11 \pm 9.83$ & 0.0449 & 0.0451 & 1.5002 & 04188 \\
\hline
\end{tabular}

phaeophytin a-like, and phaeophorbide a-like were also detected (Table 4) whereas bacteriopigments, such as bacteriochlorophyll $a$, bacteriophaeophytin alike, and spirilloxanthin were not detected in the copepod guts (Fig. 3f).
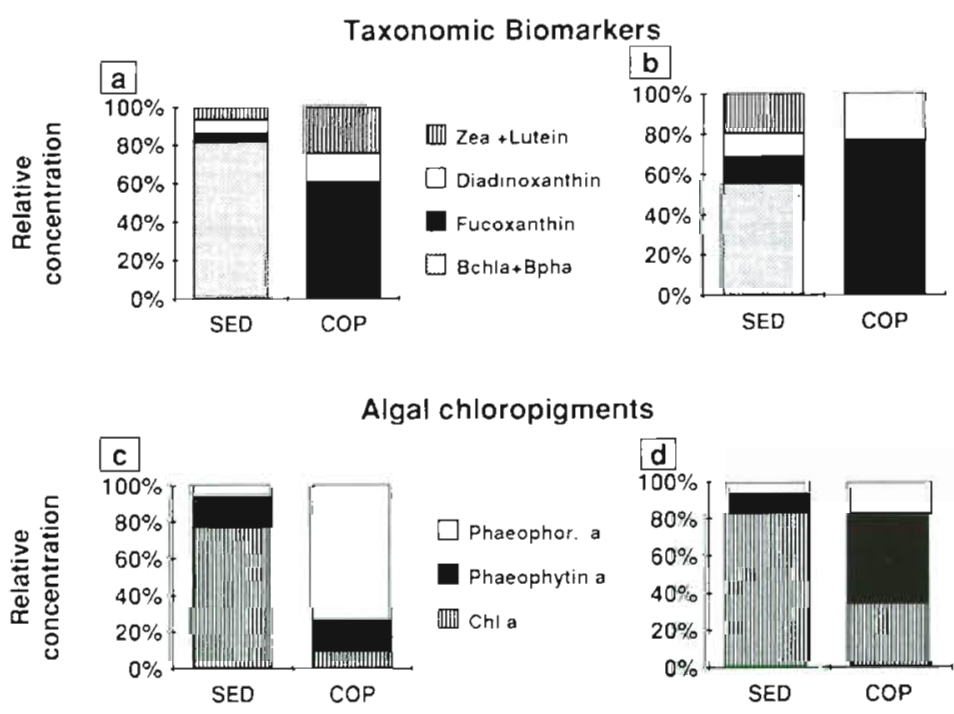

Fig. 4. Canuella perplexa. Mean relative weight proportions of selected $(a, b)$ taxonomic biomarker pigments and $(c, d)$ algal chloropigments cal. culated from sediment samples (SED) which represent the copepod habitat and from field copepod samples (COP) collected in (a, c) March 1994 at Stn $C_{1}$ and $(b$, d) October 1994 at Stn G. Zea.+lutein: zeaxanthin+lutein. Bchla+Bpha: bacteriochlorophyll a + bacteriophaeophytin $a$. Chla: chlorophyll a. Phaeophor. a: phaeophorbide a
Field comparison of pigment composition of copepods and total sediment samples

The mean relative proportions of selected biomarker pigments detected in the field copepods and in the sediment of the sampling stations were compared (Fig. 4). Bacteriopigments represented on average $40 \%$ and $16 \%$ of total pigment concentration from the March and October samples respectively (Table 4 ), and ca $70 \%$ of the selected taxonomic biomarkers (Fig. 4). This shows that purple phototrophic bacteria were abundant in the sediment but not ingested by Canuella perplexa. Results from the first field experiment (Fig. 4a) indicated that $C$. perplexa preferentially in gested diatoms (fucoxanthin and diadinoxanthin) and perhaps green microalgae and/or cyanobacteria (zeaxanthin+lutein) which were also detected in the sediment. The fucoxanthin/diadinoxanthin ratio differed strongly between the copepod contents and the sediment content in March, averaging 3.8 (Sample 1) and 4.4 (Sample 2) in copepods against 0.63 in the sediment. In the October experiment fucoxanthin and diadinoxanthin were the only carotenoids detected in the copepods, while in the sediment green microalgal and cyanobacterial biomarkers (zeaxanthin+lutein) represented approximately $20 \%$ of the selected taxo- 
nomic biomarkers (Fig. 4b). This indicates that, in the field, C. perplexa may show a strong preference for diatoms

In the sediment, the proportions of algal chloropigments (chl a, phaeophytin a-like, and phaeophorbide a-like) were similar in both March and October, with an important dominance of chl a (on average 77 to $83 \%$ ) while phaeopigments represented on average 10.5 to $17 \%$ (phaeophytin a-like), and 6 to $7 \%$ (phaeophorbide a-like) of the whole algal chloropigment concentration. The chl a/phaeopigments ratio reached $3.3-4.8$ in the sediment against $0.1-0.6$ in copepods, indicating that chl a was degraded to a higher extent in the copepods than in the sediment. Since chl a largely predominated in the sediment, it is likely that most phaeopigments in the copepods originated from the digestive degradation of chl a first to phaeophytin a (loss of $\mathrm{Mg}$ ) and second to phaeophorbide a (loss of the phytyl chain) (see Fig. 4c, d), or directly to phaeophorbide a (see Sample 2 in March; Table 4). Chl a appeared degraded to a higher extent in copepods from March samples than from October samples (phaeophorbide a-like represented on average $74 \%$ in March against 4 to $21 \%$ in October of the total chloropigment concentration). This difference may be due to the difference in the selection of the copepods during March and October sorting procedures. Indeed it is probable that 'nearly full' individuals (pigment content 0.4 to $1.5 \mathrm{ng}$ ind ${ }^{-1}$ in October) had ingested pigments more recently than 'nearly empty' individuals (pigment content 0.04 to $0.05 \mathrm{ng}$ ind $^{-1}$ in March).

\section{DISCUSSION}

\section{Applications and limitations of pigment analyses by HPLC for field studies of the diet of benthic copepods}

To our knowledge this is the first report of the application of HPLC pigment analysis for the field study of the natural diet of benthic copepods. Pigment analyses (both HPLC and fluorimetric analyses) only trace feeding on coloured and, therefore, mainly phototrophic organisms as food sources. Consequently, in the present study, we have no indication of the potential contribution of colourless microorganisms (e.g. heterotrophic bacteria) or colourless detritic particles to the diet of Canuella perplexa. In contrast, the radiotracer techniques measure the selection between autotrophic and heterotrophic microorganisms (Montagna 1995). Hence, these techniques are complementary.

HPLC separation coupled to multiwavelength spectrometry yrielus a wedih of information which allows researchers to discern the major taxonomic groups of phototrophic microorganisms utilised as food sources.
This technique allows feeding studies under natural conditions without utilisation of artificial markers. This is a major advantage, since comparably the radiotracer techniques suffer from methodological problems caused by the sorption of tracers to meiobenthic organisms not related to grazing (see e.g. Montagna \& Bauer 1988, Carman 1990) and from possible perturbation of feeding behaviour due to injections into the sediment. A major disadvantage of the HPLC method is the uncertainty regarding the extent and rate of pigment conversion into colourless products in the copepod gut. As shown for planktonic copepods, the acidic environment is particularly prone to these conversions, but the resistance during digestion and the extent of pigment transformation remain a matter of debate (Penry \& Frost 1991, Head \& Harris 1994, Swadling \& Marcus 1994).

We estimated the detection limits from peak heights exceeding twice the background noise. Even on the Spectra-Physics system, which was 20 -fold more sensitive, the detection limits $(0.1$ to $0.3 \mathrm{ng}$ per injection for carotenoids) were relatively high for copepods sampled in the field; moreover, samples had to be prepared with a high number of individuals (minimum of 400 ). Such preparations were not only time-consuming (copepods were sorted from sediment and washed under dissection microscope) but also required particular attention in order to avoid pigment degradation during the sorting. This is an important disadvantage which could limit the use of this technique, especially for routine field studies. However, the use of 'flotation methods' in saccharose or Ludox-HS solutions (Heip et al. 1974, de Jonge \& Bouwman 1977) for extracting copepods from the sediment could greatly improve the method. Thus, tests are required to determine whether these methods are compatible with the HPLC pigment analysis (interference with pigments and HPLC column).

\section{Natural diet and feeding selectivity of Canuella perplexa}

The results clearly showed that Canuella perplexa preferred microalgae and cyanobacteria to purple phototrophic bacteria. However, it was previously found that sediments from the fish ponds contained significant populations of phototrophic sulfur bacteria (e.g. $10^{6}$ to $10^{7}$ colony forming units, were enumerated per $\mathrm{cm}^{3}$ at $\mathrm{Stn} \mathrm{C}_{1}$ ). These were dominated by Chromatium gracile, Chromatium buderi, Thiocapsa roseopersicina, and Thiocystis sp. (Guyoneaud et al. in press). Our results indicate that most of these bacteria occurred in a detritic or senescent state, whereas microalgae and cyanobacteria appeared to be in a viable state. There- 
fore, we cannot exclude the possibility that the selectivity was due to the physiological status of the populations, and it remains unknown whether this copepod species refuses phototrophic sulfur bacteria in general. Previous studies have tested the value of purple phototrophic bacteria as a food source for harpacticoid copepods and the findings differed according to both the harpacticoid species and the bacterial strain involved. Decho \& Castenholz (1986) have shown that Mesochra lilljeborgi fed on a phototrophic purple bacteria (Thiocapsa sp.) and selectively assimilated this bacterium. In feeding experiments using cultures of the phototrophic bacteria Chromatium vinosum and Rhodopseudomonas palustris, it was found that Paramphiascella vararensis achieved an entire life cycle, whereas Tisbe holothuriae did not complete its life cycle when fed with C. vinosum (Rieper 1984). A recent laboratory study (Souza-Santos et al. in press) indicated that the naupiii of Amondrdia normani did not develop into adults when fed on C. gracile.

The presence of fucoxanthin and diadinoxanthin in the field copepods indicated that diatoms contributed to the naturai diei uf Canuella perplexa. Like fucoxanthin, diadinoxanthin is present in chromophytes which were mainly represented by diatoms in the sediment, but it also occurs in a few dinophyceans (Table 3). Dinophyceans contribute to the phytoplankton of the fish ponds during part of the year (Castel unpubl.). However, since peridinin was never detected in copepods nor in sediment samples it appears unlikely that planktonic dinophyceans contributed to the diet of $C$. perplexa. That diatoms represent a food source for harpacticoids of the fish ponds is not surprising since these microalgae are abundant and widely diversified in these sediments (Malissen 1979): among the described genera (26), 18 species of the genus Nitzschia dominated the diatom community in the fish ponds. Furthermore, the diatom dominance in microphytobenthic communities of such shallow water muddy environments is well established (Cariou-Le Gall \& Blanchard 1995). These results are also consistent with both laboratory and field studies (see review in Decho 1988) indicating that diatoms represent an important food source for many harpacticoid copepods. On the other hand, C. perplexa appeared to be able to feed on other types of microalgae such as green algae and/or cyanobacteria (March sampling). Recent microscopic observations (Stal et al. in press) have indicated that the cyanobacteria Anabaena, Spirulina, Phormidium, and Oscillatoria contribute to the microphytobenthic community of the fish ponds. However, no systematic data concerning the green microalgae of the fish ponds are available. The biomarkers for green microalgae (lutein and zeaxanthin) are generally associated with chl $b$. Chl $b$ and phaeopigments $b$ were not detected in sediment samples, suggesting that zeaxanthin principally originated from cyanobacteria (Table 3 ).

It should be considered that in natural environments microalgae are associated with adherent bacteria, particularly diatoms producing an extracellular mucus rich in colourless bacteria. Thus, it is probable that Canuella perplexa ingests both diatoms and the adherent bacteria, however it remains unknown whether both are assimilated as was suggested for the harpacticoid copepod Nitocra lacustris (Decho \& Fleeger 1988b).

In the copepod gut, fucoxanthin predominated over diadinoxanthin; in one sample the latter was absent in the gut whereas in other samples the fucoxanthin/ diadinoxanthin ratio was higher than in the sediment (Table 4, Fig 4). This suggests that diadinoxanthin may be more rapidly broken down than fucoxanthin during the digestive process. However, previous findings indicated that, on the contrary, diadinoxanthin is more resistant than fucoxanthin both in the sediment (Repeta 1989) and during passage through planktonic copepod guts (Mejanelle 1992). Thus, our results suggest that adult Canuella perplexa preferably ingested diatoms which contained a high fucoxanthin/diadinoxanthin ratio

Acknowledgements. We are grateful to R. Guyoneaud and Prof. P. Caumette for providing us with the reference culture of Thiocapsa roseopersicina and to L. P. Souza-Santos for providing us with the culture of Nitzschia sp. isolated from sediments of the fish ponds. We especially thank Dr A. Pastoureaud (CREMA, L'Houmeauj for her advice and information concerning HPLC techniques and for providing us with the cuiture of Dunaliella tertiolecta. Mr. F. Redero from Thermo Separation Products (Courtaboeuf, France) is acknowledged for providing us with the facilities to use the Spectra Physics fast-scanning detector. Sincere thanks to $Y$ Dubau for his useful help concerning the preparation of figures. We are also very grateful to Dr D. T Welsh and C. Hello for English corrections. This work was supported by a EU Environment program (CLEAN contract EV5V-CT92-0080).

\section{LITERATURE CITED}

Alheit J, Scheibel W (1982) Benthic harpacticonds as a food source for fish. Mar Biol 70:141-147

Bianchi TS, Dawson R, Sawangwong P (1988) The effect of macrobenthic deposit-feeding on the degradation of chloropigments in sandy sediments. J Exp Mar Biol Ecol 122:243-255

Blanchard GF (1991) Measurement of meiofauna grazing rates on microphytobenthos: is primary production a limiting factor? J Exp Mar Biol Ecol 147:37-46

Buffan-Dubau E, Castel J (in press) Diel and seasonal vertical distribution of meiobenthic copepods in muddy sediments of a eutrophic lagoon (fish ponds of Arcachon Bay). Hydrobiologia

Byron ER (1982) The adaptive significance of calanoid copepod pigmentation: a comparative and experimental analysis. Ecology 63:1871-1886 
Cariou-Le Gall V, Blanchard GF (1995) Monthly HPLC measurements of pigment concentration from an intertidal muddy sediment of Marennes-Oléron Bay, France. Mar Ecol Prog Ser 121:171-179

Carman KR (1990) Mechanisms of uptake of radioactive labels by meiobenthic copepods during grazing experiments. Mar Ecol Prog Ser 68:71-83

Carman KR, Thistle D (1985) Microbial food partitioning by three species of benthic copepods. Mar Biol 88:143-148

Castel J (1992) The meiof auna of coastal lagoon ecosystems and their importance in the food web. Vie Milieu 42:125-135

Castel J, Caumette P. Herbert R (in press) Eutrophication gradients in coastal lagoons as exemplified by the Bassin d'Arcachon and the Etang du Prévost. Hydrobiologia

Ceccherelli VU, Mistri M, Franzoi P (1994) Predation impact on the meiobenthic harpacticoid Canuella perplexa in a lagoon of the Po River Delta, Italy. Estuaries 17:283-287

Decho AW (1988) How do harpacticoid grazing rates differ over a tidal cycle? Field verification using chlorophyllpigment analyses. Mar Ecol Prog Ser 45:263-270

Decho AW, Castenholz RW (1986) Spatial patterns and feeding of meiobenthic harpacticoid copepods in relation to resident microbial flora. Hydrobiologia 131:87-96

Decho AW, Fleeger JW (1988a) Microscale dispersion of meiobenthic copepods in response to food-resource patchiness. J Exp Mar Biol Ecol 118:229-243

Decho AW. Fleeger JW (1988b) Ontogenic feeding shifts in the meiobenthic harpacticoid copepod Nitocra lacustris. Mar Biol 97:191-197

de Jonge VN, Bouwman LA (1977) A simple density separation technique for quantitative isolation of meiobenthos using the colloidal silica Ludox-TM. Mar Biol 42:143-148

Escaravage V. Castel J (1989) Application de la notion de confinement aux peuplements méiobenthiques des lagunes endiquées du Bassin d'Arcachon (côte atlantique). Acta Oecol Gener 10:1-17

Fisher LR, Kon SK. Thompson SY (1964) Vitamin A and carotenoids in certain invertebrates VII. Crustacea: Copepoda. J Mar Biol Ass UK 44:685-692

Gee JM (1987) Impact of epibenthic predation on estuarine intertidal harpacticoid copepod population. Mar Biol 96: $243-261$

Grimalt JO, de Wit R, Teixidor P, Albaiges J (1992) Lipid biogeochemistry of Phormidium and Microcoleus mats. Org Geochem 26:509-530

Guillard R, Ryther JH (1962) Studies of marine planktonic diatoms. I, Cyclotella nana Hustedt and Detonula confervacea (Cleve) Gran. Can J Microbiol 8:229-239

Guyoneaud R, Podeur K, Hirschler A, Matheron R, Caumette $P$ (in press) Distribution and characterization of anoxygenic phototrophic bacterial communities from sedıments of two coastal lagoons (Etang du Prévost and Bassin d'Arcachon, France). Hydrobiologia

Hairston NG Jr (1979) The adaptive significance of color polymorphism in two species of Diaptomus (Copepoda). Limnol Oceanogr 24:15-37

Head EJH, Harrıs LR (1994) Feeding selectivity by copepods grazing on natural mixtures of phytoplankton determined by HPLC analysis of pigments. Mar Ecol Prog Ser 110: $75-83$

Heip $C$ (1973) Partitioning of the brackish water habitat by copepod species. Hydrobiologia 41:189-198

Heip C, Smol N, Hautekiet W (1974) A rapid method of extracting meiobenthic nematodes and copenods from mud and detritus. Mar Biol 28:79-81

Herring PJ (1972) Depth distribution of the carotenoid pigments and lipids of some oceanic animals. 1. Mixed zoo- plankton, copepods and euphausiids. J Mar Biol Ass UK 52:179-189

Kleppel GS, Frazel D, Pieper RE, Holliday DV (1988) Natural diets of zooplankton off southern California. Mar Ecol Prog Ser 49:231-241

Malissen MO (1979) Contribution à l'étude des diatomées benthiques d'écosystèmes lagunaires (Bassin d'Arcachon, Francel. Systématique, dynamique, adaptation. Doct thesis, Univ Bordeaux III

Mantoura RFC, Llewellyn CA. (1983) The rapıd determination of algal chlorophyll and carotenoid pigments and their breakdown products in natural waters by reverse-phase high-performance liquid chromatography. Analyt Chim Acta 151:297-314

Mejanelle L (1992) Composition en pigments phytoplanctoniques: transport d'algues dans la colonne d'eau et dégradation par les herbivores. $J$ Rech Océanogr 17:68-75

Montagna PA (1984) In situ measurement of meiobenthic grazing rates on sediment bacteria and edaphic diatoms. Mar Ecol Prog Ser 18:119-130

Montagna PA (1995) Rates of metazoan meiofaunal microbivory: a review. Vie Milieu 45:1-9

Montagna PA, Bauer JE (1988) Partitioning radiolabeled thymidine uptake by bacteria and meiofauna using metabolic blocks and poisons in benthic feeding studies. Mar Biol 98:101-110

Montagna PA, Blanchard GF, Dinet A (1995) Effect of production and biomass of intertidal microphytobenthos on meiofaunal grazing rates. J Exp Mar Biol Ecol 185:149-165

Montagna PA, Yoon WB (1991) The effect of freshwater inflow on meiofaunal consumption of sediment bacteria and microphytobenthos in San Antonio Bay, Texas, USA. Estuar Coast Shelf Sci 33:529-547

Paanakker JE, Hallegraeff GM (1978) A comparative study on the carotenoid pigmentation of the zooplankton of Lake Maarsseveen (Netherlands) and of Lac Pavin (Auvergne, France). I. Chromatographic characterization of carotenoid pigments. Comp Biochem Physiol 60B: 51-58

Penry DL, Frost BW (1991) Chlorophyll a degradation by Calanus pacificus: dependence on ingestion rate and digestive acclimation to food resources. Limnol Oceanogr 36:147-159

Repeta DJ (1989) Carotenoid diagenesis in recent marine sediments: II Degradation of fucoxanthin to loliolode. Geochim Cosmochim Acta 53:699-707

Rieper M (1978) Bacteria as food for marine harpacticoid copepods. Mar Biol 45:337-345

Rieper M (1982) Feeding preferences of marine harpacticoid copepods for various species of bacteria. Mar Ecol Prog Ser 7:303-307

Rieper M (1984) Relationships between bacteria and marine copepods. In: Bactériologie marme. Proc Intern Colloq Centre National de la Recherche Scientifique, No. 331, Marselle, May 1982. CNRS, Paris, p 169-172

Rieper M (1985) Some lower food web organısms in the nutrition of marine harpacticoid copepods: an experimental study. Helgoländer Meeresunters 39:357-366

Rieper M. Flotow C (1981) Feeding experiments with bacteria, ciliates and harpacticoid copepods. Kieler Meeresforsch 5:370-375

Rieper-Kirchner M, Hinz K, Biddanda B (1991) Ingestion of microbially-synthesized organic aggregates and egestion of fecal pellets by marine harpacticoid copepods. Kieler Meeresforsch $8: 257-263$

Rudnick DT (1989) Time lags between the deposition and meiobenthic assimilation of phytodetritus. Mar Ecol Prog Ser 50:231-240 
Souza-Santos LP, Castel J, Santos PJP (in press) The role of phototrophic sulfur bacteria as food for meiobenthic harpactıcoid copepods inhabiting eutrophic coastal lagoons. Hydrobiologia

Stal LJ, Behrens SB, Villbrandt M, van Bergeijk S, Kruyning F (in press) The biogeochemistry of two eutrophic marine lagoons and its effect on microphytobenthic communities. Hydrobiologia

Stauber JL, Jeffrey SW (1988) Photosynthetic pigments in fifty-one species of marine diatoms. J Phycol 24: $158-172$

Swadling KM, Marcus NH (1994) Selectivity in the natural diets of Acartia tonsa Dana (Copepoda: Calanoida): comparison of juveniles and adults. J Exp Mar Biol Ecol 181. $91-103$

This article was submitted to the editor
Trueblood DD, Gallagher ED, Gould DM (1994) Three stages of seasonal successsion on the Savin Hill Cove mudflat, Boston Harbor. Limnol Oceanogr 39:1440-1454

Vanden Berghe W, Bergmans M (1981) Differential food preferences in three co-occurring species of Tisbe (Copepoda, Harpacticoida). Mar Ecol Prog Ser 4:213-219

Villanueva J, Grimalt JO, de Wit R, Keely BJ, Maxwell JR (1994) Chlorophyll and carotenoid pigments in solar saltern microbial mats. Geochim Cosmochim Acta 58: $4703-4715$

Wright SW, Jeffrey SW, Mantoura RFC, Llewellyn CA, Bjørnland T, Repeta D. Welschmeyer N (1991) Improved HPLC method for the analysis of chlorophylls and carotenoids from manne phytoplankton. Mar Ecol Prog Ser 77: $183-196$

Manuscript first received: September 28, 1995

Revised version accepted: February 15, 1996 